\title{
KONFLIK ISLAM DAN ISRAEL DI PALESTIN: TENTANGAN, ISU DAN PENYELESAIANNYA DALAM KARYAAL-FARUQI
}

\author{
Tasnim Abdul Rahman a Zuriati Mohd Rashid ${ }^{b}$, Wan Sabri Wan Yusof ${ }^{c}$, Ahmad Nabil Amir \\ ${ }^{a}$ Faculty of Islamic Contemporary Studies (FKI), Universiti Sultan Zainal Abidin (UniSZA), Kampus \\ Gong Badak, 21300 Kuala Terengganu, Terengganu, Malaysia \\ ${ }^{b}$ Centre for Language Studies and Generic Development (PBI), Universiti Malaysia Kelantan (UMK), \\ 17600 Kampus Jeli, Kelantan, Malaysia \\ ${ }^{c}$ Kolej Universiti Islam Sultan Azlan Shah (KUISAS), Bukit Chandan, 33000 Bandar DiRaja Kuala \\ Kangsar, Perak, Malaysia \\ ${ }^{d}$ Islamic Renaissance Front, Pavilion KL, 168 Jalan Bukit Bintang, 55100 Kuala Lumpur, Wilayah \\ Persekutuan, Malaysia \\ *Corresponding author: E-mail: wansabri@kuisas.edu.my,Tel: +605-7732323
}

\author{
Article history \\ Received: $12 / 08 / 2014$ \\ Received in revised form:15/2/2015 \\ Accepted: $15 / 2 / 2015$
}

Abstract

This paper discusses the views of al-Faruqi on the issue of Israel-Palestine as critically presented in his work Islam and the Problem of Israel. It aims to analyze his perspective on the significant impact of Israel's occupation in the Gaza's strip, explaining in detail some historical issues and suggesting solution to the conflict. The research attempts to investigate his stand concerning the Israel-Palestine war, the way he analyzes the issue and its comparison with other works of similar orientation. The research is based on descriptive, analytical and comparative method, by describing in depth al-Faruqi's work and its significance in addressing the plight and catastrophic consequence of war, and its comparison with other works produced on this theme. The research findings and its conclusions are important to test the ideas propounded by al-Faruqi to effectively end the conflict in the West Bank.

Keywords: al-Faruqi, Islam and the Problem of Israel, Israel-Palestine conflict, development of conflict, Middle East, Zionism

\begin{abstract}
Abstrak
Kertas ini membincangkan konflik Israel-Palestin daripada rangka pemikiran Prof Ismail Raji al-Faruqi berdasarkan karyanya Islam and the Problem of Israel. Ia bertujuan menyorot pandangan beliau mengenai kesan pendudukan Israel di Gaza, menjelaskan secara terperinci tentang isu-isu sejarah di samping mengkaji penyelesaian yang dikemukakan. Persoalan penting yang diutarakan dalam kajian ini adalah apakah pandangan al-Faruqi tentang isu perang Israel-Palestin, bagaimana beliau menangani dan memberikan analisisnya tentang isu tersebut dan perbandingan dengan karya-karya lain seumpamanya. Kajian ini menggunakan metode deskriptif, analitis dan komparatif, dengan memaparkan karya al-Faruqi dan sumbangannya dalam membahas permasalahan umat dan kesan bencana peperangan selain turut membandingkannya dengan beberapa karya lain yang menangani isu yang sama. Penemuan dan kesimpulan kajian memberikan impak yang signifikan untuk menguji kekuatan dan keberkesanan idea al-Faruqi dalam merungkai dan menamatkan konflik di Asia Barat.
\end{abstract}

Kata kunci: al-Faruqi, Islam and the Problem of Israel, Konflik Palestin-Israel, perkembangan konflik, Timur Tengah, Zionisme 


\subsection{PENGENALAN}

Kertas ini cuba menggarap penulisan Prof. Dr. Ismail Raji al-Faruqi (1921-1986) tentang permasalahan Islam dan Zionisme yang dikupas dalam bukunya Islam and the Problem of Israel (1980). Ia berusaha membahas pandangan yang diutarakannya dan tema-tema penting yang diangkat dalam karya ini tentang sejarah pendudukan Israel dan agenda ekspansionis serta pengaruh imperialis Barat di Timur Tengah. Ia turut melihat penyelesaian Islam yang dikemukakannya dan relevansinya dengan tuntutan demokratik semasa. Perbincangan dimulakan dengan menghuraikan latar belakang buku, kerangka bab, tema asas dan aspek-aspek penting yang ditanganinya. Setelah itu diberikan lakaran tentang pandangan al-Faruqi tentang faham Zionisme, aspirasi politik dan sejarah perjuangannya di Timur Tengah. Ia turut memberikan perbandingan dengan pemikiran dan analisis lain yang dikemukakan tentang isu ini. Akhirnya suatu rumusan dan analisis ringkas dikemukakan tentang pemikiran al-Faruqi dan penyelesaiannya terhadap isu-isu keselamatan dan perdamaian di wilayah Israel-Palestin.

\subsection{LATAR BELAKANG BUKU}

Buku ini pertama kali diterbitkan pada tahun 1980 oleh Islamic Council of Europe, London. Dalam karya ini, al-Faruqi memberikan kupasan yang substantif dan mengemukakan pandangan yang analitis tentang sejarah dan latar belakang gerakan Zionisme dan ketegangan yang ditimbulkannya di Asia Barat. Kritikan dan penelitiannya yang mendalam mendapat perhatian yang meluas di dunia Islam. Terakhir ia diulang cetak (cetakan keempat) oleh The Other Press, Kuala Lumpur pada 2006. Buku ini mengetengahkan pandangan yang tuntas tentang sejarah dan perancangan strategik Israel untuk menguasai Palestin dan merampas wilayahnya yang diteruskan dengan dasar ekspansionis dan teror yang didukung oleh kuasa besar. Ini penting untuk diketengahkan, kerana, menurut al-Faruqi, tiada literasi yang membahas dengan terperinci tentang permasalahan Zionis dan ancaman kolonialisme Barat terhadap Islam, sejak penghijrahan Yahudi secara masif pada 1933. Ini dijelaskan dalam mukaddimahnya: "Unfortunately, there is no Islamic literature on the subject. The need for this analysis of the problem is, therefore, as great as the present moment which calls upon the Arab World in particular and the Muslim World in general to accept Israel as an integral member of a world-of-Muslim-nations in Asia-Africa." (al-Faruqi, 2006: 1) Isu pertentangan Islam dan Zionisme ini merupakan isu yang telah dianalisis dengan terperinci sepanjang karier penulisannya, kerana selain buku ini, al-Faruqi turut menulis beberapa makalah penting tentang isu ini seperti Islam and Zionisme (1983), Whither the Palestinians (1984), Usul al-Sahyuniyah fi al-Din al-Yahudi (1964) (An Analytical Study of the Growth of Particularism in Hebrew Scripture), dan Al-Milal al-Mu 'asirah fi al-Din al-Yahudi (1968) yang disiarkan sejak tahun 1960an. Penulisannya menzahirkan aspirasi dan cita-cita perjuangan yang kental untuk menuntut keadilan dan kebebasan bagi rakyat Palestin di samping mengusulkan cara bagi menghentikan keganasan dan ketidakadilan yang memburukkan usaha perdamaian di rantau Timur Tengah.

\subsection{KERANGKA BAB}

Buku ini memuatkan 10 bab yang merumuskan ide dan pemikirannya tentang permasalahan Islam dan Israel. Ia menyingkap latar sejarah yang menyumbang kepada ketegangan antara Islam dan Israel, dan mengkaji permulaan yang membawa kepada pendudukan Yahudi di Palestin. Ia turut menyorot pertentangan ideologi antara Islam, Yahudi dan Kristian serta menganalisis motif yang mendasari faham imperialisme dan kolonialisme Barat yang menyerbu dengan kekuatan militer ke Timur Tengah. Ini dicerakinkan dalam 10 bab yang disusun seperti berikut: Bab I: The ThreeCornered Nature of the Problem. Bab II: Apercu of Jewish History in the Christian West Prior to the Emancipation. Bab III: The Emancipation and its Aftermath. Bab IV: The Romantic Relapse of Europe. Bab V: Zionism: The European Jew's Counsel of Despair. Bab VI: Jewish Universalism and Ethnocentrism. Bab VII: Zionism as Religion. Bab VIII: Zionism as Politics. Bab IX: Islam and Judaism. Bab X: Islam and Zionism.

Isu yang ditangani dalam keseluruhan bab ini mengarah kepada persoalan dasar tentang permasalahan Islam dan Israel serta pergelutan ideologi dan perbenturan politik yang telah berakar sejak zaman permulaan Islam sehingga kejatuhannya (622-1924 M) yang berlanjutan sehingga sekarang. Ianya dirumuskan oleh penerbit buku ini dalam pengantarnya: "The problem of Israel confronting the Muslim World today has neither precedent nor parallel in Islamic history. The Muslim World has tended to regard it as another instance of Modern colonialism, or at best, as a 
repetition of the Crusades. The author shows how Israel is neither one of these; but that it is both and more. The book goes into the nature of Zionism, its history, what has kept it alive, Islam's verdict concerning Israel today, the question on whether the secular Palestinian state is an answer to the problem of Israel, and many other topics about this great problem." (al-Faruqi, 2006).

\subsection{TEMA ASAS}

Tema dan perspektif asas yang diketengahkan dalam buku ini menjelaskan tentang faktor sejarah yang mencetuskan perang antara Islam dan Zionisme di Palestin. Ia membincangkan perkembangannya dalam sejarah sejak termeterainya perjanjian Madinah, pengusiran Yahudi dari Jazirah Arab, penyerbuan Islam ke Empayar Rome dan Byzantine dan Perang Salib serta merumuskan beberapa ide dan pandangan tentang penyelesaiannya. Ia turut menyingkap kesan daripada kebudayaan dan pemikiran Eropah terhadap perjuangan Zionis. Ini ditangani dengan jelas dalam karya ini yang memperlihatkan penerobosan pengaruh sekularisme, nasionalisme, rasisme dan faham romantisisme Eropah dalam pemikiran Zionis.

Idea pokok yang digarap dalam buku ini adalah berpangkal daripada 17 persoalan yang cuba diangkat dan diilhamkan oleh al-Faruqi, dalam usaha menilik dan mencari jawapan terhadap kemusykilan tersebut: "What is the nature of Zionism? What is its history? What is the internal force which has kept it alive? What is the nature of its appeal to the mind of the Western Jew? of the Western Christian? If Judaism is old, and Zionism very new, how do they differ and what is their relation to each other? Why did Zionism insist on having a state - Israel? Why did the State of Israel behave as it did towards its neighbors? Must Israel always remain a Zionist state? How does the advent of the State of Israel look from the standpoint of Islam? How is the ideological war between Israel and the Muslim World to be treated? What is Islam's verdict today concerning Israel? May it be recognised under the terms of the shari'ah? What changes or conditions need to be instituted in order to make such recognition legitimate? Is the secular Palestinian state the Islamic answer to the problem of Israel? Suppose the whole machinery of the State of Israel were dismantled, what would Islam replace it with? How would Islamic constitutional law, under the circumstances, regulate future Muslim-Jewish relations? These and other questions are the subject of the present work." (al-Faruqi, 2006: 6)

\subsection{ZIONISME}

Dalam takrifnya tentang Zionisme, al-Faruqi (2006: 92) merujuknya sebagai "A movement launched by Theodore Herzl following his dissilusionment by the Dreyfus Affair. It was designed to transform Palestine and its adjacent territories into a Jewish state, "as Jewish as England is English." Skandal Dreyfus adalah krisis politik di Perancis (antara 1894-1906) melibatkan Alfred Dreyfus (1859-1935) kapten Yahudi Perancis yang dituduh membocorkan rahsia militer Perancis kepada Jerman yang telah menimbulkan anti-semitisme yang meluas di Eropah dan konspirasi untuk menafikan bangsa Yahudi yang mendorong Herzl untuk mewaraskannya dengan melancarkan gerakan menuntut tanah air asal bagi diaspora Yahudi, seperti dibayangkannya: "if France - bastion of emancipation, progress and universal socialism - [can] get caught up in a maelstrom of anti-Semitism and let the Parisian crowd chant 'kill the Jews!' Where can they be safe once again - if not in their own country? Assimilation does not solve the problem because the Gentile world will not allow it as the Dreyfus affair has so clearly demonstrated" (al-Faruqi, 2006).

Menurut al-Faruqi, gerakan yang dilancarkan oleh Theodore Herzl untuk menguasai tanah Palestin ini berteraskan politik Machiaveli dengan taktik ganas untuk merobah peta negeri Palestin menjadi penempatan Yahudi. Ini dibayangkan dengan jelas dalam kenyataannya yang mengkritik dasar Zionisme yang membelakangi pertimbangan moral dan akhlak dalam tindakan mereka: "Zionism's pursuit of this objective is thoroughly Machiavellian. Its singleminded purpose is given absolute priority over all considerations, including the moral." (al-Faruqi, 2006)

Menyorot sejarah awal kepada perang ini, ia dapat dikesan daripada rencana politik yang dirancang dalam Kongres Zionis Pertama di Basel, Switzerland pada 1897 untuk mendirikan tanah air Yahudi di Palestin dan dirumuskan dalam Protokal Asas. Ini diperkuat dengan peranan Suruhanjaya Diraja British, dan media massa seperti Daily Chronicle dan Pall Mall Gazette dalam mempropagandakan aspirasi ini. Theodore Herzl menuntut Khalifah Uthmaniyah untuk menyerahkan wilayah Palestin dengan rundingan jual beli. Permintaan itu ditolak oleh Sultan Turki, dan Zionis 
bertindak balas dengan mencetuskan huru hara yang membawa kepada Perang Dunia Pertama yang mengakibatkan beberapa wilayah dalam jajahan Uthmaniyah jatuh ke tangan Perancis dan British. Perjanjian Balfour yang ditandatangani pada tahun 1917 turut meletakkan Palestin di bawah naungan British dan sekaligus memberi mandat kepada Yahudi untuk memasuki Tebing Barat.

Dalam hal ini, al-Faruqi (2006) menulis: "defying its provisions, the Zionist leadership began to force the way into Palestine for the Jewish refugees from Europe with arms. When Britain resisted their attempt in fear of evoking the Palestinians into renewing their armed struggle, Zionism opted for terrorism." Beliau mengkritik kebobrokan dasar Zionis yang menggunakan taktik teror dan militer untuk mengusir pelarian Palestin, sungguhpun ditolak oleh pemerintah British kerana bimbang dengan tindak balas dan penentangan bersenjata daripada rakyat Palestin yang akan menyulitkan usaha perundingan secara damai. Menurut al-Faruqi, penghijrahan secara massa oleh penduduk Yahudi ini turut didalangi oleh Amerika yang kuat mendukung aspirasi Zionis tersebut dengan mandat Pertubuhan Bangsa-Bangsa Bersatu (PBB). Ini terpapar dalam kenyataannya: "He (President Harry Truman) openly supported the Zionist demand for immediate admission of 100,000 Jewish immigrants to Palestine, and thus for the repeal of the White Paper. He put the whole power and might of the United States of America behind the Zionist attempt to win a United Nations resolution for partition of the country and the setting up of a Jewish State." (al-Faruqi, 2006) Peranan PBB dan Amerika dalam mengusahakan pemisahan wilayah di Tebing Barat ini telah menyumbang kepada penemuan negara Yahudi secara haram di tanah Palestin.

Pengisytiharan negara Israel pada tahun 1948 telah meluaskan peranan Zionisme dalam percaturan politik di Tebing Barat dengan kekerasan militer yang dikerahkan untuk mengusir dan menghapuskan penempatan Palestin dan membungkam elemen-elemen penentangan dan protes daripada massa. Ini disuarakan oleh al-Faruqi: "It was after 1948 that Zionism uncovered its nature and began to operate in the open. Its plan was to empty Palestine of its native inhabitants and to occupy their lands, farms, homes and all movable properties. In so doing, Zionism was guilty of naked robbery by force of arms; of wanton, indiscriminate slaughter of men, women and childen; of destruction of men's lives and properties." (al-Faruqi, 2006: 93). Kemusnahan yang dicetuskan oleh kebiadapan Zionis ini dikecam keras oleh al-Faruqi, dengan perampasan wilayah dan perampokan ganas terhadap tanah, rumah dan harta yang dipusakai umat Islam secara sah.

Namun dalam pemerhatiannya yang objektif, tindakan Zionisme ini dibezakan al-Faruqi dengan agama Yahudi, yang dianggap sebagai millah yang sah, seperti dijelaskan dalam makalahnya "Islam and Zionism" (1983) "Islam tidak menentang agama Yahudi dan memandangnya sebagai agama Tuhan. Islam menentang politik Zionisme dan tindakan Zionis." Tentangan terhadap gerakan Zionis ini turut disuarakan oleh pemikir Islam yang lain, seperti Muhammad Asad (asal Leopold Weiss) dalam bukunya The Road to Mecca (1954), yang menyuarakan kritikan dan bantahannya terhadap Zionisme, sewaktu berhujah dengan pemimpin Zionis seperti Chaim Weizmann: "Jerusalem was an entirely new world to me...although of Jewish origin myself, I conceived from the outset a strong objection to Zionism. Apart from my personal sympathy for the Arabs, I considered it immoral that immigrants, assisted by a foreign Great Power, should come from abroad with the avowed intention of attaining to majority in the country and thus to dispossess the people whose country it had been since time immemorial."

Kesan daripada peperangan dan pendudukan Israel ke atas Palestin telah membawa kemusnahan yang dahsyat terhadap kedua belah pihak dengan siri penembakan, pengeboman dan serangan maut yang turut mengorbankan nyawa kanak-kanak, seperti dirakamkan oleh Anjum Rahman (2006) dalam artikelnya "The Israel-Palestin Problem: The Perspective of a New Zealand Muslim": "There have been too many casualties on both sides of this conflict. Since 29 September 2000, 121 Israeli children and 724 Palestinian children have been killed. These children are the most innocent victims of this long-running dispute. The majority of deaths of Israeli children are the result of suicide bombers or of Palestinian gunfire."

Gerakan Zionis yang menggunakan kekerasan tentera untuk bertindak ke atas penduduk Islam dan Kristian di Sempadan Gaza dan meneruskan keganasan dan pembantaian ke atas masyarakat sivil, jelas bertentangan dengan semangat yang dipertahankan dalam Deklarasi Balfour, yakni surat yang ditulis oleh Menteri Luar Britain Arthur kepada Lord Rothschild dan dikirimkan kepada Federasi Zionis yang menerangkan posisinya dengan jelas, "His Majesty's Government view with favour the 
establishment in Palestine of a national home for the Jewish people, and will use their best endeavours to facilitate the achievement of this object, it being clearly understood that nothing shall be done which may prejudice the civil and religious rights of existing non-Jewish communities in Palestine, or the rights and political status enjoyed by Jews in any other country." (Schneer, Jonathan, 2010: 464) Semangat yang tercerna daripada Pengisytiharan Balfour ini jelas mempertahankan hak sivil dan politik penduduk yang menempati wilayah Palestin, justeru membungkam kebiadapan yang diteruskan oleh Zionis terhadap umat Islam di sana.

Tindakan Israel juga bertentangan dengan Pengisytiharan Hak Asasi Manusia Sejagat (Universal Declaration of Human Rights, UDHR), yang menjamin hak asasi manusia. Ia turut melanggar ketetapan Rang Undang-undang Hak Asasi Manusia Antarabangsa, yang dirangka dalam Perhimpunan Agung Pertubuhan Bangsa-Bangsa Bersatu, dan Pengisytiharan Kaherah mengenai Hak Asasi Manusia dalam Islam yang diikrarkan pada 5 Ogos 1990, yang menegaskan: "Sekiranya berlaku penggunaan kuasa dan dalam kejadian berlakunya konflik bersenjata, adalah dilarang membunuh orang-orang yang tidak bersengketa seperti orang tua, wanita dan kanak-kanak. Mereka yang cedera dan sakit berhak untuk mendapatkan rawatan perubatan dan tahanan-tahanan perang berhak diberikan makanan, tempat tinggal dan pakaian." (artikel 3 (a)). Menurut al-Faruqi (2006: 93) sejak pendudukan Zionis ke atas Palestin pada 1948, ia telah merampas penempatan dan hak terhadap keselamatan dan survival umat Islam yang diteruskan dengan taktik keganasan dan teror. Ini dinyatakannya dengan jelas: "In its occupation of Palestine since 1948, Zionism has perpetrated immeasurable injustice against the Palestinians who survived its onslaught and remained in their homes. Internationally, the Zionist state has, since its establishment in 1948, terrorized the whole region, massacred the innocent by the thousands, destroyed innumerable villages, and drained the resources and energies of a whole generation of a hundred million awakening Arabs on futile wars which it imposed upon them."

Ketegangan yang dicetuskan turut memberi impak yang serius dalam menghalang kemajuan dan inisiatif ke arah perdamaian dan dialog, dan melumpuhkan "usaha mewujudkan keamanan dan memberikan keadilan kepada rakyat Palestin" dan "hasrat untuk melihat tertegaknya sebuah negara Palestin yang merdeka, bebas dan makmur." (Harakah Daily, 2012)

Huraian al-Faruqi tentang konflik Israel-Islam ini turut mengetengahkan tuntutan pembaharuan, kebangkitan, revolusi dan penentangan rakyat terhadap Israel serta perjuangan mereka yang keras, seperti dilakarkannya: "Despite all these attempts at keeping them down, backward and ignorant, at dividing and impoverishing them, dispossessing them of their land and inheritance, at isolating them from their Arab brothers to the North, East and South, from world currents and developments, the Palestinians made remarkable advances." (al-Faruqi, 2006) Baginya, ketahanan yang ditunjukkan dalam menghadapi Zionis ini merupakan benteng dan aset yang ampuh bagi umat dalam menangkis serangan Zionis yang berusaha menghapuskan peta Palestin dari semenanjung tanah Arab.

\subsection{PERBANDINGAN}

Kebanyakan naratif tentang isu Israel-Palestin menyorot tema-tema khusus tentang percaturan politik Barat di Israel, kebangkitan gerakan intifada dan perjuangan politik Hamas, perebutan pengaruh Fatah dan Hamas, memoir perang, dan isu sempadan antara Palestin dan Israel. Edward Said (1994), seorang intelektual asal Palestin, mengupas dalam bukunya The Politics of Dispossesion: The Struggle for Palestinian Self-Determination berkenaan perjalanan politik di wilayah Palestin dan perjuangan rakyatnya menuntut hak yang dirampas. Buku ini menghimpunkan tiga puluh enam tulisannya yang pernah dimuatkan dalam suratkhabar, majalah, ulasan esei, bab dalam buku, dan interbiu. Perbincangannya merangkumi tiga bahagian utama, "Palestin dan Rakyat Palestin," "Dunia Arab," dan "Politik dan Intelektual". Analisanya secara keseluruhan tidak lepas daripada menggarap persoalan Palestin dengan meluas dan kritis. Dalam karyanya yang lebih awal The Question of Palestine (1992), Edward Said mengupas persoalan dasar melibatkan isu pendudukan, moral, identiti, dan politik di Palestin serta menelusuri perkembangan penting dalam pergolakan di Timur Tengah daripada gerakan intifada kepada Perang Teluk kepada persidangan keamanan yang historis di Madrid.

Noam Chomsky \& Ilan Pappe dalam Gaza in Crisis: Reflections on Israel's War against the Palestinians (2010) menghuraikan dengan menyeluruh tentang kedudukan dan kegentingan nasib Palestin, penglibatan Amerika dalam percaturan politik di Asia Barat, Nakbah dalam sejarah Israel, 
"the Ghettoization of Palestine" dan perjanjian damai di Timur Tengah yang berakhir dengan kebuntuan. Buku yang diselenggarakan oleh Frank Barat ini pada umumnya bertujuan untuk membangkitkan kesedaran dan perhatian dunia yang meluas terhadap persoalan Palestin, yang digarap daripada temubual dengan Profesor Noam Chomsky dan Ilan Pappe, sejarawan Israel. Ia menyentuh tentang isu-isu agama, sejarah, politik dan kemanusiaan melibatkan "konflik Israel-Palestin" yang berlarutan, dan memberikan pencerahan tentang langkah untuk menangani dan menghentikan penindasan hak asasi dan ketidakadilan dalam "sejarah Israel-Palestin" yang panjang ini.

Roger Garaudy (1989) dalam The Founding Myths of Modern Israel membongkar mitos teologi tentang "Holocaust", "Promised Land", "Chosen People", "Ethnic Purification" "anti-fasisme Zionis", "tentang tanah tanpa manusia untuk manusia tanpa tanah air" yang didakwanya digunakan sebagai "justifikasi dogmatik" oleh pelobi Israel-Zionis di Amerika dan alat politik kerajaan Israel untuk merampas rakyat Palestin dari tanah mereka dan mempertahankan keabsahan tuntutan Yahudi ke atas Jerusalem. Dari perspektif Malaysia, Anidah Robani telah mengupas secara substatif berkenaan polisi dan dasar kerajaan terhadap isu Palestin dalam bukunya The Palestinian Issue: A Malaysian Perspective 1957-2003 (2009) yang menganalisis hubungan politik antara Malaysia dan PLO (Pertubuhan Pembebasan Palestin - Palestine Liberation Organization) dan negara-negara Arab. Ia menyentuh tentang sikap dan komitmen kerajaan dalam menangani isu ummah ini dari 1957-1989 dalam era pentadbiran empat Perdana Menteri. Ini dikaji berdasarkan dokumentasi sejarah tentang dasar dan polisi luar yang dibentuk berasaskan pertimbangan politik yang pragmatik dalam menyuarakan hak dan memperjuangkan nasib rakyat Palestin.

Berbeza dengan tulisan-tulisan tersebut, karya al-Faruqi sebaliknya membincangkan punca dan latar yang menimbulkan pertentangan dan faktor yang menyumbang kepada pergolakan di Tebing Barat. Beliau memaparkan dengan berkesan hubungan sejarah sejak Perang Salib, pembantaian ke atas Yahudi oleh Kristian-Nazi di Jerman dan kesan kebangkitan revolusi nasionalis Eropah dalam mempengaruhi percaturan politik Zionis di Tebing Barat.

Al-Faruqi turut memberikan pandangannya tentang penyelesaian Islam (Islamic solution) yang mengetengahkan aspirasi yang universal untuk mewujudkan pemerintahan Islam, idea yang berbeza dengan penyelesaian dan cadangan lain yang dikemukakan. Tema ini digarap secara berkesan dengan nilai falsafah yang tuntas dalam bukunya Islam: "Truly, then, the world order that Islam envisages is an ideal order of national and international relations, one which constitutes the only answer to the continuing malaise of the world situation. By comparison to it, a world peace based on atomic terror, on the balance of power, or on the imperial tyranny of any ummah over the others is considered by Muslims as satanic." (al-Faruqi, 1995: 67) Baginya, kebejatan sistem yang berdasar kepada pandangan sekular, tirani dan otokratik, dan dasar imperialis yang digunapakai hari ini bukanlah jawapan kepada permasalahan dunia. Sebaliknya ia terletak kepada orde Islam yang mampu memulihkan dan mengatur hubungan sejagat dengan prinsip tauhid, yang berunsurkan keyakinan agama dan moral. Pandangannya yang kritis dalam menganalisis isu ini adalah bersifat realistik dan kontemporari yang membuka kefahaman baru tentang penyelesaian Islam dalam menangani konflik tersebut, dan menyediakan landasan yang jelas dalam memahami ketegangan yang tercetus berhubung isu Palestin dengan cara yang meyakinkan.

\subsection{PENYELESAIAN}

Dalam merangka penyelesaian terhadap permasalahan yang gawat tentang isu Islam dan Zionisme ini, al-Faruqi telah menggariskan penyelesaian yang tuntas dalam bukunya Islam and the Problem of Israel yang diperincikan seperti berikut (al-Faruqi, 2006: 113):

(1) First, the Arab states of the Near East must undergo a transformation from being caricatures of the Western national states to becoming a single, united Islamic state. The Arab states are literally all creations of Western colonialism. They must all be dismantled and their populations reorganized into the Islamic state. Their laws which again for the most part they had inherited from Western colonialism ought to be discarded in favor of the Shari'ah, or law of Islam. The Islamic state emerging from their union should abolish all frontiers between them, all their individual defense establishments, and assume all responsibility for defense and foreign affairs. Only if this is achieved may the Arab Muslims of the Near East stand ready to implement the Islamic solution of the problem of Israel. 
(2) Second, Israel, the Zionist state, would be dismantled; by force, if necessary. The institution of the Zionist state is a positive evil, and so is all its defense establishment. This leaves the ummah of Jews as covenanter with the Islamic state for peace. The Jewish citizens of Israel would not be required to move. On the contrary, they would be invited to dwell in any city or village of the whole Islamic state, not only in some pieces of real estate on the West Bank of the Jordan and in the Gaza strip as Zionism is presently asking.

(3) Thirdly, once the bouleversement this solution brings has settled down, there is no reason why the Jews, as dhimmi citizens of the Islamic state, may not keep all the public institutions they have so far developed in Palestine (Courts of law, learned societies of art and culture, public corporations, schools, colleges and universities) to continue in their operation, whether in any locality of Palestine or anywhere else where Jews might choose to dwell. Henceforth, their vision and their efforts would be directed toward upholding and promoting Judaism, not the Western ideologies of decadence and aberration.

Penyelesaian ini mungkin kelihatan radikal dalam konteks sekarang yang lebih melihat kepada tuntutan sejagat dan penyelesaian yang demokratik. Al-Faruqi menggariskan tiga kaedah penyelesaian yang agak keras dengan menfokuskan kepada peranan negara-negara Arab dan umat Islam untuk mewujudkan pemerintahan Islam, menumpaskan gerakan Israel dan Zionis, dan keperluan untuk menegakkan undang-undang shariah yang universal. Ia menuntut institusi dan negara Israel dihapuskan serta pertahanan ketenteraannya dilumpuhkan. Peranan umat turut digembleng untuk menakluk dan menundukkan Israel dan akhirnya menerima umat Yahudi ke dalam wilayah Islam. Dalam konteks sekarang, penyelesaian ini mungkin dianggap radikal dan akan diketepikan kerana pendirian kebanyakan negara anggota Pertubuhan Kerjasama Islam (Organization of Islamic Conference - OIC) adalah ke arah usaha perdamaian dan kewujudan bersama entiti Yahudi dan Islam di Tebing Barat.

Beliau turut membayangkan kemungkinan Islam akan berjaya menawan dan menguasai Bayt alMaqdis dalam perang di Tebing Barat, dan berakhir dengan tegaknya negara Islam yang mempertahankan keadilan dan kebebasan bagi umat Kristian dan Yahudi di bawah pemerintahan Islam. Beliau menggambarkan kemungkinan ini dengan menukil pesan Sultan Muhammad al-Fateh (penakluk Konstantinopel) kepada Gennadius Scholarius, pendeta Konstantinopel dan pemimpin ummah bukan-Islam di bawah empayar beliau: "Be the Patriarch of your ummah in peace. May Allah protect you. To you, our friendship is pledged in all circumstances and under all conditions, wherever it may benefit you. May you enjoy all the privileges hitherto enjoyed by your predecessors!" (alFaruqi, 2006: 114)

Pandangan al-Faruqi tentang kemungkinan tertegaknya negara Islam dengan menyingkirkan Israel sebagai kuasa dominan di Tebing Barat ini turut dibayangkan oleh Youssef Nada, tulang belakang dalam pimpinan jemaah Ikhwan Muslimin (Muslim Brotherhood) yang menegaskan "Palestin dan Israel sebagai dua buah negara adalah sesuatu yang tidak akan berjaya" (Douglas Thompson, 2013).

Beberapa penyelesaian lain yang menekankan perdamaian dua hala dan mengiktiraf semangat demokratik, yang bercanggah dengan idea al-Faruqi, telah disuarakan oleh pemimpin dunia Arab, seperti diusulkan oleh Menteri Luar Kerajaan Arab Saudi, Putera Saud al-Faisal: "This [2002 Arab Peace Initiative] is the way toward security...Israel can't keep the land and want security at the same time. It has to withdraw and give the Palestinians their rights. If Israel does that, the Arab states will put an end to the state of war. That will give Israel its security." Raja Abdullah dari Jordan turut menegaskan penyelesaian yang sama yang menuntut kemerdekaan dan kedaulatan mutlak ke atas Palestin sebagai syarat untuk negara-negara Arab memberi jaminan keselamatan terhadap Israel: "The Palestinian right to statehood and their cry for justice and a homeland free of occupation remain the Arab people's foremost cause. In Jordan, the "final status" issues including borders, refugees, security and Jerusalem are at the heart of our priorities. This means making real the promise of a viable, independent, sovereign Palestinian state, as part of a two-state agreement that resolves all final-status issues and guarantees security for Israel."

Pandangan ini turut diutarakan oleh Ismail Haniyeh, Perdana Menteri Palestin, yang menuntut supaya Israel berundur dari sempadan, sebagai syarat untuk mengadakan kerjasama dan mengikat 
perjanjian jangka panjang sekaligus mengiktiraf Israel: "If Israel withdraws to the 67 borders, then we will establish a peace in stages...Number one, we will establish a situation of stability and calm which will bring safety for our people what (Hamas founder) Sheikh (Ahmed) Yassin called a longterm hudna (truce). If Israel declares that it will give the Palestinian people a state and give them back all their rights, then we are ready to recognize them." Idea ini turut diperjuangkan oleh Shaykh Muhammad Abduh yang memperkasai berdirinya perkumpulan "At-Taqrib bayna Ahlil Islam wa ahlil Kitab (pendekatan antara Muslim dan ahli kitab). Semangat al-Qur'an yang mempertahankan kebebasan dan keadilan ini turut menjadi landasan dalam pemerintahan khalifah di Baitulmaqdis, seperti diamati oleh Mohd Roslan Mohd Nor: "it is interesting to note that the Quranic frameworks on eliminating racism, promoting equality and assurance of freedom and rights is being implemented since early days of Islam as can be noted in the case of Islamicjerusalem." (Mohd Roslan Mohd Nor, 2011)

Menurut al-Faruqi, strategi dan tindakan kombatif yang berkesan perlu untuk mendesak Israel berundur dari Tebing Barat dan usaha juga perlu untuk menghalang kuasa-kuasa besar daripada terus melindungi Israel yang "tidak mungkin bertindak ganas tanpa dukungan langsung dari Amerika dan Eropah.” (Harakah Daily, 2012) Dokongan perlu digembleng dari negara-negara anggota Pertubuhan Kerjasama Islam (Organization of Islamic Conference - OIC), Pertubuhan Bangsa-Bangsa Bersatu (PBB), dan badan-badan swadaya masyarakat, untuk memperjuangkan aspirasi rakyat Palestin ke arah mewujudkan kestabilan di rantau tersebut.

\subsection{DAPATAN}

Dalam buku ini, al-Faruqi telah menggariskan pandangan dan idea-idea yang kritis dalam usaha untuk menangani permasalahan umat Islam di Palestin. Beliau telah mengusulkan langkah penyelesaian yang berkesan dalam memberantas ancaman Zionis dan mengakhiri peperangan dan kemusnahan yang dicetuskannya. Selain mengutip idea dan pandangan daripada pemikir Islam dan Barat, beliau turut mengemukakan ijtihadnya yang radikal dalam menghuraikan permasalahan ini.

Dua asas penting yang difokuskan dalam penelitiannya adalah kedudukan Israel dan Zionis serta dasar ekspansionis yang diteruskannya dan penyelesaian Islam yang rasional. Beliau menggariskan penyelesaian Islam yang ideal yang menuntut penggemblengan kekuatan untuk memberantas gerakan Zionis, dan keperluan untuk menerima Yahudi sebagai umat di bawah pemerintahan Islam. Pemikirannya secara jelas dapat dirumuskan seperti berikut: (1) beliau mendukung aspirasi rakyat Palestin untuk meraih keamanan dan keselamatan di tanah air mereka yang dirampas (2) wilayah mereka yang diduduki Israel secara haram sejak 1948 harus dikembalikan dan diberikan pampasan yang sewajarnya (3) kepentingan dan nasib umat Islam di Palestin harus diperjuangkan oleh seluruh komuniti Islam dengan segenap kekuatan.

Tuntutan dan idea yang fundamental yang dikemukakan oleh al-Faruqi ini mencerminkan harapannya untuk mencari jalan penyelesaian yang tuntas terhadap konflik tersebut. Meneliti pandangannya ini kita dapat memahami perjuangan dan perhatiannya terhadap persoalan Palestin yang ditinggalkannya sejak 1948. Setelah meninggalkan tanah airnya di Jaffa, Palestin, beliau berhijrah ke Amerika dan memulakan sejarah perjuangan yang baru untuk memperbaharui pemikiran Islam dan membawa idealisme pembaharuan dan kebangkitan. Sumbangannya penting dalam menggerakkan dialog antara peradaban, memperjuangkan hak rakyat Palestin yang tertindas, dan menentang kekerasan dan agenda politik Zionis, serta dasar ekspansionisnya yang zalim. Menurutnya: "Ketidakadilan Zionisme begitu kompleks, terlalu banyak dan mengerikan, hingga tidak ada cara lain untuk menghentikannya kecuali melalui kekerasan perang dengan menghancurkan tentera, negara dan seluruh institusi awam Zionis." (Al-Faruqi, 2011).

Tulisannya jelas mencabar kedudukan dan kepentingan Zionis di Timur Tengah dan mengkritik dasar teroris dan pembantaian yang dilakukan ke atas rakyat Palestin. Usahanya menyekat kemaraan Israel, ketegasan mempertahankan aspirasi rakyat Palestin dan gugatannya terhadap gerakan Zionis, mungkin antara faktor yang telah membawa kepada pembunuhannya, seperti dilaporkan oleh akhbar New Straits Times (1986): "Muslim intellectuals and community leaders in United States believe that the assassinations were carried out to warn other Muslim intellectuals against standing up for Palestinian rights and cultural self-expression." 
Idealisme dan falsafah perjuangannya yang kental mempertahankan nilai keadilan, menjunjung semangat persefahaman, dan perdamaian ini, jelas diungkapkan oleh Dr. Chandra Muzaffar (2001) dalam ucaptamanya pada syarahan Ismail al-Faruqi Memorial Lecture: "Professor Ismail al-Faruqi was undoubtedly one of the most accomplished and one of the most illustrious thinkers that the Muslim world has produced in recent decades. His writings, which span a whole spectrum of social concerns, have contributed immensely to a better understanding of tawhid, Islamic culture, and interfaith dialogue among both Muslims and non-Muslims. As a committed intellectual who translated ideas into action, the late Professor al-Faruqi was an honest and principled voice in the struggle for a just world. It was because of his own integrity that he regarded morality in public life as fundamental to social justice."

\subsection{KESIMPULAN}

Melalui perbincangan ringkas tentang buku Islam and the Problem of Israel ini, kita telah dapat melihat dan memahami struktur penulisan serta kerangka manhajnya dengan jelas. Penulisan ini penting dalam menyumbang kepada perbahasan yang mendalam tentang sejarah perang IsraelPalestin. Kekuatan karya dan nilai pemikirannya yang fenomenal berakar daripada kekuatan analisis dan manhaj yang diketengahkannya dalam memberikan landas dan kefahaman yang jelas tentang latar konflik, dan diperkukuh dengan kesanggupan merungkai dan mencadangkan jalan penyelesaian yang praktis.

Melalui perbincangannya yang substantif, beliau telah mengetengahkan beberapa pandangan dan rumusan yang penting berkaitan isu perang di sempadan di samping menggariskan penyelesaian yang tuntas dan meyakinkan. Dalam mendepani permasalahan politik dan situasi kekacauan di Semenanjung Gaza, penyelesaian yang dikemukakan ini dapat direalisasikan bagi menghadapi ancaman Zionisme dan memastikan kewujudan bersama yang sejahtera (peaceful co-existance) antara agama-agama di Baitul Maqdis (Islamic Jerusalem).

Tulisan al-Faruqi ini juga perlu diangkat dan dibincangkan dengan kritis, serta dianalisis dengan lebih meluas dan konstruktif. Ini penting untuk melahirkan karya yang berupaya membahas dan menangani isu perang Israel-Palestin daripada metode dan aspirasi yang dibawa oleh al-Faruqi dalam buku ini.

\section{RUJUKAN}

Abdul Halim Ramli. (2002). Pemikir Islam Prof Ismail Ragi al-Faruqi. Segamat: Gubah Publisher.

Al-Faruqi, I. R. (1962). 'Urubah and Religion: An Analysis of the Dominant Ideas of Arabism and of Islam as Its Heights Moment of Consciousness, vol. 1 of On Arabism. Amsterdam: Djambatan.

Al-Faruqi, I. R. (1964). Usul al-sahyuniyah fi al-din al-yahudi. Kaherah: Ma'had al-Dirasat al-'Arabiyyah al'Aliyah.

Al-Faruqi, I. R. (1968). Al-milal al-mu 'asirah fi al-din al-yahudi. Kaherah: Ma'had al-Buhuth wa al-Dirasat al'Arabiyyah.

Al-Faruqi, I. R. (1983). "Islam and Zionism", dalam John L. Esposito, ed. Voices of Resurgent Islam. Oxford University Press.

Al-Faruqi, I. R. (1984). "Whither the Palestinians”. Islamic Order. 3(1), 73-78.

Al-Faruqi, I. R. (1995). Islam. Bestville: Amana Publications.

Al-Faruqi, I. R. (2006). Islam and the Problem of Israel. Cet. 4. Kuala Lumpur: The Other Press.

Al-Faruqi, I. R., \& Sopher, D. E. (1974). Historical Atlas of The Religions of The World. New York: Macmillan.

Anidah Robani. (2009). The Palestinian issue: A Malaysian perspective 1957-2003. Kuala Lumpur: IIUM Press.

Anjum Rahman. (2006). The Israel-Palestin problem: The perspective of a New Zealand muslim. Aotearoa Ethnic Network Journal. 1(1), 14-19.

Asad, Muhammad. (1954). The road to Mecca. London: Max Reinhardt.

Assassination motive behind al-Faruqi killings. (1986, 20 August). New Straits Times. h. 5

Chandra Muzaffar. (2001). Morality in public life: The challenge before religion. The American Journal of Islamic Social Sciences. 19 (3), 90-110. 
Chomsky, Noam \& Pappe, Ilan. (2010). Gaza in crisis: Reflections on Israel's war against the Palestinians. Chicago: Haymarket Books.

Drouin, Michel. (2006). The Dreyfus affair dictionary. France: Flammarion.

Garaudy, R. (1989). Israel: Suatu kajian politik zionisme. Batu Caves: Thinkers Library.

Mohd Roslan Mohd Nor. (2011). "Protecting non-muslim: Its implementation during early muslim rule of IslamicJerusalem." Al-Bayan -Journal of Quran and Hadith Studies, 9: 209-222.

Muhammad Kamal Hassan. (2011). "Al-Wasatiyyah as understood and defined by Islamic scholars in contemporary Singapore and its consistency with Ismail Al Faruqi's vision of Ummatan Wasatan." The American Journal of Islamic Social Sciences, 28 (3): 35-57.

Palestin: PKR berkongsi hasrat dengan PAS. (2012, 16 Februari). Harakah Daily. <bm.harakahdaily.net/index.php/berita-utama/8162-palestin-pkr-berkongsi-hasrat-dengan-pas>

Sabaruddin Hussein. (2012). Konspirasi yahudi: Perang dan penaklukan. Kuala Lumpur: PTS Islamika.

Said, Edward W. (1992). The question of Palestine. New York: Vintage Books.

Said, Edward W. (1994). The politics of dispossession: The struggle for Palestinian self-determination, 19691993. New York: Pantheon Books.

Schneer, Jonathan (2010). The Balfour Declaration: The Origins of the Arab-Israel Conflict. T.t.p.: Random House.

Thompson, Douglas \& Nada, Youssef. (2013). Di sebalik Ikhwan Muslimin. Batu Caves: PTS Islamika. 